\title{
The Mutual Effect of Irrigation Scheduling and Foliar Spray of Silica Nanoparticles on Basil Plant
}

Mahmoud, M. A. ${ }^{1}$; A. Y. Shala ${ }^{2}$ and Nahed M. Rashed ${ }^{3}$

${ }^{1}$ Water Requirements and Field Irrigation Department, Soils, Water and Environment Research Institute. Agricultural Research Center, Giza, Egypt.

${ }^{2}$ Medicinal and Aromatic Plants Research Department, Horticulture Research Institute. Agricultural

Research Center, Giza, Egypt.

E-mail address awad.shala@yahoo.com

${ }^{3}$ Vegetable and Ornamental Dept., Fac. of Agric. Damietta Univ., Damietta, Egypt.

E-mail address mahmoud_abdalla96@yahoo.com- awad.shala@yahoo.com-rashed_nahed@du.edu.eg

\section{ABSTRACT}

Afield experiment was conducted during 2016 and 2017 in the Research Farm of Sakha Agricultural Research Station, Kafr El-Sheikh Governorate, Egypt to evaluate the mutual effect of irrigation scheduling and silica nanoparticles on Ocimum basilicum L. vegetative growth, yield, chemical composition and some water relations. Irrigation scheduling treatments were 1.2, 1.0 and 0.8 of cumulative pan evaporation (CPE) while a foliar spray of silica nanoparticles at 30,60,90 ppm and distilled water as a control. Results showed that 0.8 of $\mathrm{CPE}$ decreased vegetative growth characters, fresh and oil yield ha ${ }^{-1}$ and transpiration rate nevertheless, increased chlorophyll content, oil\% and stomatal resistance value in the two cuts of both seasons. Silica nanoparticles at 60 and $90 \mathrm{ppm}$ increased all characters likely oil yield increased by $52.2 \%$ over the control. Irrigation at 1.0 of CPE with silica nanoparticles at $60 \mathrm{ppm}$ recorded the highest values of vegetative growth, fresh and oil yield, chlorophyll content and oil\%. The highest essential oil components were $\alpha$-terpineol and linalool in plants sprayed with 60 and 90 ppm silica nanoparticles under all irrigation treatments. The greatest values of seasonal consumptive use and applied irrigation water were observed from plants treated with 1.2 of CPE while, the lowest values obtained from 0.8 of CPE. The highest values of productivity of irrigation water and water productivity were recorded after 1.0 of CPE. Finally, plants treated with 1.0 of CPE combined with silica nanoparticles at $60 \mathrm{ppm}$ showed enhanced vegetative growth, fresh and oil yield, stomatal resistance value, oil components while, decreased transpiration rate. Furthermore, decreased water consumptive use 7\% and applied irrigation water $5 \%$ while, increased water productivity by $24 \%$ and productivity of irrigation water by $20 \%$ compared to 1.2 of CPE without silica nanoparticles spray.

Keywords: Irrigation scheduling, Ocimum basilicum L., Silica nanoparticles, Oil\%, yield

\section{INTRODUCTION}

It is well-known that water is one of the main significant aspects influencing plant growth and yield. Moreover, water resources are needed to be used effectively because of the further competition of the restricted water resources between domestic, industrial and agricultural consumptions. In addition to, water resources limitation and anticipated impacts of climate change especially in arid and semi-arid regions as in Egypt. For effective management and to improve the productivity of irrigation water, both temporal and spatial distribution of irrigation supply is important. The timely irrigation supply with the desired quantity is defined as irrigation scheduling (Rai, 2017). In addition, the water supply is one of the greatest critical cultivation conditions which considerably affected the yield and essential oil content of various spices and herb crops (Zehtab-Salmasi et al., 2001, Singh et al., 2002 and Delfine et al., 2005). Water deficit decreased plant height and total dry mass on basil plants (Alishah et al. 2006). Irrigation at 0.75 of CPE increased herbage and oil yield of basil plant compared to 0.25 of CPE, but oil content and quality were not influenced by irrigation regime (Singh 2002). Water stress reduces plant height and basil yields, while the essential oil is positively affected (Ekren et al., 2012).

Ocimum basilicum L. (basil), also known as French or sweet basil, is a widespread annual herb of the Lamiaceae (Labiatae) family grown as a perennial in warm tropical climates, native to India and East Africa (Hiltunen and Holm, 2003). Essential oils are separated from basil by steam distillation from the leaves and flowering tops and are consumed for food seasoning, dental and oral products, perfumes and in traditional rituals and medicines (Simon et al., 1990). The principal components of the oil are linalool, methyl cinnamate, eugenol, 1,8-cineole, methyl chavicol, geranial, neral and caryophyllene oxide (Lee et al., 2005 and Sajjadi, 2006).

Nanoparticles (NPs) have obtained intensified attention in recent past due to their unique distinguished properties. Accordingly the small size of silica nanoparticles involves new physical, chemical and biological characteristics (Monica and Cremonini, 2009). Silicon is a very significant part of the earth's crust and is the second most plentiful element, consisting around 28 $\%$ of the earth's crust (Sommer et al., 2006). However, Si is accumulated in several plants up to $10 \%$ on a dry weight basis, but it is not considered an essential element for regular plant growth and development (Hodson et al., 2005). Contrarily, Epstein and Bloom, (2005) suggested that $\mathrm{Si}$ should be deemed an essential element for plant growth. However, regardless its essentiality, Si has been stated to mitigate, the adverse impacts of abiotic stresses such as heavy metals toxicity, drought, and salinity in plants, (Ahmed et al., 2014; Zhu and Gong, 2014 and Keller et al., 2015) and biotic stresses like pest injury and plant diseases (Cote-Beaulieu et al., 2009). Si has enhanced water stress tolerance in plants by keeping leaf water potential, leaves erectness, stomatal conductance, the structure of xylem vessels under high transpiration rates, and photosynthetic activity (Gong et al., 2003).

The purpose of this study was to evaluate the responses of basil plant to irrigation scheduling and determine whether foliar spray of silica nanoparticles could mitigate the adverse impact of water deficit treatment on vegetative growth, yield, essential oil \% and oil components and some water relations of basil plants under study region. 


\section{MATERIALS AND METHODS}

A field experiment was performed in 2016 and 2017 growing seasons in Sakha Agricultural Research
Station ( $31^{\circ} 07^{\prime} \mathrm{N}$ Latitude, $30^{\circ} 05^{\prime}$ E Longitude), Kafr El-Sheikh Governorate, North Nile Delta of Egypt. The agro-meteorological data of Sakha Station during both growth seasons are presented in (Table A).

Table A. The meteorological data of Sakha Agro-meteorological Station in 2016 and 2017.

\begin{tabular}{|c|c|c|c|c|c|c|c|c|c|}
\hline \multirow[b]{2}{*}{ Season } & \multirow[b]{2}{*}{ Month } & \multicolumn{3}{|c|}{ Air temperature } & \multicolumn{3}{|c|}{ Relative humidity \% } & \multirow{2}{*}{$\begin{array}{c}\text { Wind Speed } \\
\text { Mean } \\
\left(\mathrm{km} \mathrm{d}^{-1}\right)\end{array}$} & \multirow{2}{*}{$\begin{array}{c}\text { Pan evaporation } \\
\text { Mean } \\
\left(\mathrm{mm} \mathrm{d}^{-1}\right)\end{array}$} \\
\hline & & $\begin{array}{c}\text { Max. } \\
\left({ }^{\circ} \mathrm{C}\right)\end{array}$ & $\begin{array}{l}\text { Min. } \\
\left({ }^{\circ} \mathrm{C}\right)\end{array}$ & $\begin{array}{c}\text { Mean } \\
\left({ }^{\circ} \mathrm{C}\right)\end{array}$ & $\begin{array}{c}\text { Max. } \\
(\%)\end{array}$ & $\begin{array}{c}\text { Min. } \\
(\%)\end{array}$ & $\begin{array}{c}\text { Mean } \\
(\%)\end{array}$ & & \\
\hline \multirow{7}{*}{2016} & April & 30.03 & 18.62 & 24.33 & 81.60 & 41.80 & 61.70 & 87.10 & 5.94 \\
\hline & May & 30.40 & 22.80 & 26.60 & 71.00 & 45.80 & 58.40 & 97.00 & 6.47 \\
\hline & June & 33.60 & 26.30 & 29.95 & 75.70 & 46.60 & 61.15 & 112.80 & 8.07 \\
\hline & July & 33.70 & 26.10 & 29.90 & 82.70 & 56.80 & 69.75 & 105.50 & 7.84 \\
\hline & Aug. & 33.60 & 26.00 & 29.80 & 84.30 & 56.30 & 70.30 & 92.80 & 7.74 \\
\hline & Sept. & 32.60 & 24.30 & 28.45 & 83.10 & 51.80 & 67.45 & 95.10 & 5.91 \\
\hline & Oct. & 29.80 & 21.70 & 25.75 & 82.40 & 55.30 & 68.85 & 92.20 & 3.57 \\
\hline \multirow{7}{*}{2017} & April & 26.50 & 21.60 & 24.05 & 79.40 & 50.80 & 65.10 & 89.30 & 4.64 \\
\hline & May & 30.60 & 25.80 & 28.20 & 77.70 & 45.60 & 61.65 & 106.50 & 6.59 \\
\hline & June & 32.50 & 28.10 & 30.30 & 80.10 & 51.40 & 65.75 & 102.60 & 7.10 \\
\hline & July & 34.20 & 29.00 & 31.60 & 84.40 & 57.60 & 71.00 & 80.90 & 6.44 \\
\hline & Aug. & 33.90 & 28.30 & 31.10 & 85.90 & 55.30 & 70.60 & 70.20 & 6.04 \\
\hline & Sept. & 32.50 & 25.90 & 29.20 & 86.30 & 50.30 & 68.30 & 85.70 & 5.37 \\
\hline & Oct. & 28.70 & 24.00 & 26.35 & 81.10 & 54.70 & 67.90 & 73.20 & 3.26 \\
\hline
\end{tabular}

The relevant chemical properties of the experimental soil (Table B) were determined before cultivation process according to Page et al., (1982). Soil field capacity, permanent wilting point and available water were conducted according to James, (1988). The soil bulk density was determined by the method of Vomocil, (1957). The particle-size distribution was evaluated by Klute, (1986).

Table B. Some physical and chemical soil properties of the experimental soil as mean values of both growth seasons.

\begin{tabular}{|c|c|c|c|c|c|c|c|c|c|c|c|}
\hline $\begin{array}{l}\text { Soil } \\
\text { depth } \\
\text { (cm) }\end{array}$ & $\begin{array}{c}\text { Field } \\
\text { capacity } \\
(\%)\end{array}$ & $\begin{array}{c}\text { Wilting } \\
\text { point } \\
(\%)\end{array}$ & $\begin{array}{c}\text { Bulk } \\
\text { density } \\
\left(\mathrm{Mg} \mathrm{m}^{-3}\right)\end{array}$ & $\begin{array}{c}\text { Available } \\
\text { soil water in } \\
\text { mm }\end{array}$ & $\begin{array}{c}\text { Total } \\
\text { porosity } \\
(\%) \\
\end{array}$ & $\begin{array}{c}\text { Sand } \\
(\%)\end{array}$ & $\begin{array}{l}\text { Silt } \\
(\%)\end{array}$ & $\begin{array}{l}\text { Clay } \\
(\%)\end{array}$ & $\begin{array}{c}\text { Texture } \\
\text { class }\end{array}$ & $\underset{\left(\mathbf{d S ~}^{-1}\right)}{\mathbf{E C}_{\mathrm{e}}}$ & $\begin{array}{c}\text { pH } \\
1: 2.5\end{array}$ \\
\hline $0-15$ & 46.40 & 25.60 & 1.10 & 34.30 & 58.49 & 24.68 & 25.18 & 50.14 & Clayey & 2.67 & 8.50 \\
\hline $15-30$ & 40.30 & 24.10 & 1.15 & 27.90 & 56.60 & 24.39 & 24.43 & 51.18 & Clayey & 2.75 & 8.66 \\
\hline $30-45$ & 37.40 & 22.30 & 1.21 & 26.90 & 54.34 & 23.91 & 24.06 & 52.03 & Clayey & 3.58 & 8.72 \\
\hline $45-60$ & 34.80 & 20.70 & 1.30 & 27.50 & 50.94 & 23.77 & 23.58 & 52.65 & Clayey & 3.96 & 8.93 \\
\hline Mean & 39.70 & 23.20 & 1.19 & & 55.09 & 24.19 & 24.31 & 51.50 & Clay & 3.24 & \\
\hline
\end{tabular}

\section{Time of irrigation}

The available soil water was converted to water depth in $\mathrm{mm}$ (Table, B) and it was $117 \mathrm{~mm}$. At every irrigation, the equivalent amount of evaporation that can occur was estimated, while this amount of available soil water is being used. Irrigation was timed when cumulative pan evaporation (CPE) amounted to 97.6, 117.1 and $146.4 \pm 5 \mathrm{~mm}$ for each treatment of 1.2, 1.0, and 0.8 of CPE

Sweet basil seeds were acquired from Medicinal and Aromatic Plants Research Department, Horticulture Research Institute, Agricultural Research Center, Egypt. The seeds were sown in the greenhouse at the beginning of March 2016 and 2017 seasons into a mixture of vermiculite and peat moss $(2: 1)$, the seedlings at $10 \mathrm{~cm}$ were transplanted on April 15 $5^{\text {th }}, 2016$ and 2017 respectively on $30 \mathrm{~cm} \times 50 \mathrm{~cm}$ plant spacing. The experiment was performed on a split-plot design with three replications. The irrigation scheduling treatments i.e. $1.2,1.0$ and 0.8 of cumulative pan evaporation (CPE) were in the main plot while silica nanoparticles were allocated in the sub-plots. The silica nanoparticles treatments were sprayed twice one month before each cut with 30, 60 and 90 ppm concentrations and distilled water as a control. All agricultural practices were conducted according to Agricultural Research Center recommendations

Irrigation treatments were implemented to basil plants two weeks after transplanting on May $1^{\text {st }} 2016$ and 2017. The applied irrigation water to each experimental plot was measured using PVC spile tubes $(10 \mathrm{~cm}$ inner diameter of $80 \mathrm{~cm}$ length). The spile tubes were utilized to let water flows from field ditches into each plot. The effective water head above the cross section center of the spile was kept constant at $10 \mathrm{~cm}$ using a fixed sliding gate type. Stage gauges were placed in each plot to measure the water depth that flows through the spiles. The water amount in each application was recorded and the consumed time was also monitored using a stop watch. The amount of water delivered through the spile tube was calculated according to Majumdar (2002) by the following equation:

$$
\mathbf{q}=\mathbf{C A} \sqrt{ } \mathbf{2} \mathbf{g h}
$$

Where $q$ is irrigation water discharge in $\mathrm{cm}^{3} \mathrm{~s}^{-1}, \mathrm{C}$ is a discharge coefficient (0.62) and it (determined in the experiment, $A$ is an inner cross section area of the irrigation spile in

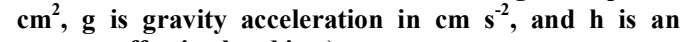
average effective head in c).

Area of each plot was $42 \mathrm{~m}^{2}(6 \mathrm{~m} \times 7 \mathrm{~m})$, and volume of water applied in each plot was calculated by substituting $\mathrm{q}$ in the following equation: 


\section{$\mathbf{Q}=\mathbf{q} \times \mathbf{t} \times \mathbf{n}$}

Where $Q$ is water volume in $\mathrm{m}^{3} /$ plot, $q$ is discharge in $\mathrm{m}^{3} \mathrm{~min}^{-1}$, $t$ is a total time of irrigation in min and $n$ is a number of spile tube per each plot.

Characterization and preparation of silica nanoparticles (Si NPs) suspension: Si NPs; $18 \mathrm{~nm}$ in average diameters, were purchased from Nano. Tech. Egypt Co., Dreamland, Wahat Road, $6^{\text {th }}$ October, Egypt. Si NPs; were prepared from rice husk, in the spherical form (98\% purity). Si NPs size was examined by transmission electron microscopy (TEM). The obtained Si NPs size was ranged from 10 to $12 \mathrm{~nm}$. By using the Brunauer-Emmett-Teller (BET) method (Brunauer, 1945), the result showed that the maximum specific surface of the sample was about $320 \mathrm{~m}^{2} \mathrm{~g}^{-1}$.

Plants were harvested at mid flowering stage July $15^{\text {th }}$ and September $15^{\text {th }}$ in 2016 and 2017 and the following data were recorded: plant height $(\mathrm{cm})$, number of main branches, plant fresh weight (g) and plant dry weight (g). Fresh herb yield $\left(\mathrm{kg} \mathrm{ha}^{-1}\right)$ : The plants were harvested by hand with a knife $10 \mathrm{~cm}$ above the land surface, and instantly weighed for the obtained plot yield. Then the plot yield was converted to a yield $\mathrm{ha}^{-1}$.

Chlorophyll content (SPAD) values were performed using the SPAD-502 meter (Minolta Co. LTD, Japan). The device measures transmission of red light at $650 \mathrm{~nm}$, at which chlorophyll absorbs light, as well as transmission of infrared light at $940 \mathrm{~nm}$, at which no absorption happens (Hoel and Solhaug, 1998).

Herb essential oil percentage. The plants were harvested and 100 gm fresh herb was used to a $3 \mathrm{~h}$ waterdistillation using a Neo-Clevenger apparatus according to British Pharmacopoeia., (1963). The essential oil ratio of the plants was defined by a volumetric method $(\mathrm{ml} / 100 \mathrm{~g})$ and the isolated essential oils were kept at $4{ }^{\circ} \mathrm{C}$ until the gas chromatography analysis which was conducted according to Robert, (1995).

Stomatal resistance $\left(\mathrm{s} \mathrm{cm}^{-1}\right)$ and transpiration rate ( $\mu \mathrm{g} \mathrm{H}_{2} \mathrm{O} \mathrm{m}^{-2} \mathrm{~s}^{-1}$ ). Were determined before each cut by a Portable Steady state Porometer (LI - COR Model LI 1600) on fully expanded top 3- 4 leaves on the shoots of six randomly selected plants.

Water consumptive use (CU) was estimated by using the following equation (Israelsen and Hansen, 1962).

$$
\mathbf{C U}=\sum_{i=1}^{n=4} \operatorname{Di} \mathbf{x} \operatorname{Bd} \mathbf{x}(\theta 2-\theta 1) / 100
$$

Where $\mathrm{CU}$ is a water consumptive use in $\mathrm{cm}, \mathrm{Di}$ is a soil depth layer $(15 \mathrm{~cm}), \mathrm{Bd}$ is a soil bulk density in $\mathrm{g} \mathrm{cm}^{-3}$ for this depth, $\theta 1$ is a percent of soil moisture before irrigation, $\theta 2$ is a percent of soil moisture, 24 hours after irrigation; $\mathbf{n}$ is a number of soil layers.

Productivity of irrigation water (PIW) and water productivity (WP).

The productivity of irrigation water and water productivity of fresh herb yields as $\mathrm{kg} \mathrm{m}^{-3}$ were calculated according to Ali et al. (2007) and Ghane et al. (2010) as follows:

$$
\begin{aligned}
& \text { Productivity of irrigation water }\left(\mathrm{kg} \mathrm{m}^{-3}\right)= \\
& \qquad \begin{array}{c}
\text { Herb yield } \\
\mathrm{kg} \mathrm{ha}
\end{array} \\
& \hline \text { Amount } \text { of applied water in } \mathrm{m}^{3} \mathrm{ha}^{-1}
\end{aligned}
$$

$$
\text { Water productivity }\left(\mathrm{kg} \mathrm{m}^{-3}\right)=\frac{\text { Herb yield in } \mathrm{kg} \mathrm{ha}^{-1}}{\text { water consumptive use in } \mathrm{m}^{3} \mathrm{ha}^{-1}}
$$

Statistical analysis

Statistical analysis of variance (ANOVA) was performed using COSTAT software. Differences between treatments means were investigated by Duncan's Multiple Range Test (Snedecor and Cochran, 1980).

\section{RESULTS AND DISCUSSION}

\section{Vegetative growth}

Plant height, number of main branches, fresh and dry weight were significantly differed among the different irrigation scheduling treatments (Table, 1). The greatest values of previous mentioned vegetative growth characters resulted from plants grown under treatment at 1.0 of cumulative pan evaporation (CPE) without significant variations among 1.2 of CPE in most cases. Plants raised slowly in growth parameters under 1.2 of $\mathrm{CPE}$ and 1.0 of $\mathrm{CPE}$ compared to those under 0.8 of $\mathrm{CPE}$. Vegetative growth reduction under 0.8 of $\mathrm{CPE}$ could be attributed greatly to photosynthesis impairment and a decline in photosynthetic products to transmit to the growing parts of the plant (Lakpale et al., 2007).These finding partly agree with the results of Alishah et al., (2006), Moosavi et al., (2014) and Asgharipour and Mosapour, (2016) stated that the increase of water deficit decreased plant height and total dry mass of basil and fennel plants. Related findings were formerly reported by Shao et al., (2008) and Karim et al., (2017).

For Si NPs spraying treatments, the least growth characteristics were obtained in the sprayed plants with tap water. Spraying plants with 60 and 90 ppm of Si NPs contributed to higher plant growth parameters than the other spraying treatments without significant variations in most cases in between for the two cuts in both seasons. The improvement of growth parameters by foliar application of Si NPs can be attributed to promotion of some elements transport in xylem sap ( $\mathrm{Mg}, \mathrm{Fe}$, and etc.), enhancement of uptake capacity of water and fertilizers, stimulation of the activity of some key enzymes such as nitrate reductase, increase of Indole-3-acetic acid (IAA) concentration and enhanced antioxidant activity like, SOD, CAT and POD and indicated that nanoparticles mediated effect on plants growth and development is concentration dependent (Laware and Shilpa, 2014 and Le et al., 2014).

A significant interaction among irrigation scheduling treatments and Si NPs spraying was found to exist on the vegetative traits. It was obvious that under 1.0 of CPE sprayed plants $(60 \mathrm{ppm})$ in most cases for the two cuts in both seasons had significantly greater growth rates than those sprayed with tap water (Table, 1). Application of silica nanoparticles increased all growth parameters under 1.0 of CPE condition as these findings may be expected to that silicon increases sustainability of cell wall by forming a layer. Overall one gram of silica nanoparticles with $7 \mathrm{~nm}$ diameter has an absorption surface equal to $400 \mathrm{~m}^{2}$. So, silica nanoparticles application affect xylem humidity and 
water translocation which result in water use efficiency improvement (Wang and Naser., 1994). These results were in agreement with the findings of Kalteh et al., (2014) and Le et al., (2014)

Table 1. Effect of irrigation scheduling and silica nanoparticles on plant height (cm), main branches number, fresh and dry weights (g) of Ocimum basilicum L. during the two cuts of both seasons 2016 and 2017.

\begin{tabular}{|c|c|c|c|c|c|c|c|c|c|c|}
\hline \multirow{4}{*}{ Treatments } & \multicolumn{10}{|c|}{ Plant height $(\mathrm{cm})$} \\
\hline & \multicolumn{10}{|c|}{$1^{\text {st }}$ Season 2016} \\
\hline & \multicolumn{5}{|c|}{ 1st cut } & \multicolumn{5}{|c|}{$2^{\text {nd }}$ cut } \\
\hline & Control & 30 ppm & 60 ppm & 90 ppm & Mean & Control & 30ppm & 60 ppm & 90 ppm & Mean \\
\hline $1.2 \mathrm{CPE}$ & $72.66 \mathrm{ab}$ & $73.00 \mathrm{ab}$ & $74.00 \mathrm{a}$ & $73.66 \mathrm{a}$ & $73.22 \mathrm{a}$ & $79.6 \mathrm{ab}$ & $80.6 \mathrm{ab}$ & $82.26 \mathrm{a}$ & 78.93abc & $80.35 \mathrm{a}$ \\
\hline $1.0 \mathrm{CPE}$ & $72.00 \mathrm{ab}$ & $72.66 \mathrm{ab}$ & $75.08 \mathrm{a}$ & $74.66 \mathrm{a}$ & $73.24 \mathrm{a}$ & $76 \mathrm{abcd}$ & $81.66 \mathrm{ab}$ & $81.66 \mathrm{ab}$ & $77.00 \mathrm{a}-\mathrm{d}$ & $79.08 \mathrm{a}$ \\
\hline $0.8 \mathrm{CPE}$ & $63.30 \mathrm{e}$ & $69.00 \mathrm{c}$ & $70.66 \mathrm{bc}$ & $72.00 \mathrm{ab}$ & $68.75 b$ & $69.83 d$ & $71.83 \mathrm{~cd}$ & $77.50 \mathrm{a}-\mathrm{d}$ & $74.16 \mathrm{bcd}$ & $73.33 b$ \\
\hline Mean & $69.32 \mathrm{c}$ & $71.55 \mathrm{~b}$ & $73.24 \mathrm{a}$ & $73.44 \mathrm{a}$ & & $75.14 b$ & $78.03 \mathrm{ab}$ & $80.47 \mathrm{a}$ & $76.70 \mathrm{ab}$ & \\
\hline \multicolumn{11}{|c|}{$2^{\text {nd }}$ Season 2017} \\
\hline $1.2 \mathrm{CPE}$ & $75.66 \mathrm{bc}$ & $76.33 \mathrm{ab}$ & 77.33ab & 77.00ab & $76.58 \mathrm{~b}$ & $81.36 \mathrm{ab}$ & $82.38 \mathrm{ab}$ & $84.09 \mathrm{a}$ & $80.68 \mathrm{abc}$ & $82.13 a$ \\
\hline $1.0 \mathrm{CPE}$ & $75.66 b c$ & $76.66 \mathrm{ab}$ & $78.66 a$ & $78.66 \mathrm{a}$ & $77.41 \mathrm{a}$ & $77.73 a-d$ & $83.52 \mathrm{ab}$ & $83.52 \mathrm{ab}$ & $78.75 \mathrm{abcd}$ & $80.88 \mathrm{a}$ \\
\hline $0.8 \mathrm{CPE}$ & $66.33 \mathrm{e}$ & $72.00 \mathrm{~d}$ & $73.66 \mathrm{~cd}$ & $75.00 \mathrm{bc}$ & $71.75 \mathrm{c}$ & $71.32 \mathrm{~d}$ & $73.34 \mathrm{~cd}$ & 79.12abcd & $75.72 \mathrm{bcd}$ & $74.88 b$ \\
\hline Mean & $72.55 \mathrm{c}$ & $75.00 \mathrm{~b}$ & $76.55 \mathrm{a}$ & $76.88 \mathrm{a}$ & & $76.80 \mathrm{~b}$ & $79.75 \mathrm{ab}$ & $82.24 \mathrm{a}$ & $78.38 \mathrm{ab}$ & \\
\hline \multicolumn{11}{|c|}{$\begin{array}{c}\text { Main branches No. } \\
1^{\text {st }} \text { Season } 2016\end{array}$} \\
\hline $1.2 \mathrm{CPE}$ & $7.33 \mathrm{~cd}$ & $8.00 b c$ & $8.33 b$ & $8.33 b$ & $8.00 \mathrm{~b}$ & $10.33 \mathrm{ab}$ & $11.00 \mathrm{a}$ & $10.00 \mathrm{ab}$ & $9.66 \mathrm{abc}$ & $10.25 \mathrm{a}$ \\
\hline $1.0 \mathrm{CPE}$ & $8.00 \mathrm{bc}$ & $8.33 b$ & $9.33 \mathrm{a}$ & $9.33 \mathrm{a}$ & $8.75 a$ & $10.00 \mathrm{ab}$ & $9.66 \mathrm{abc}$ & $11.00 \mathrm{a}$ & $10.33 \mathrm{ab}$ & $10.25 \mathrm{a}$ \\
\hline $0.8 \mathrm{CPE}$ & $6.33 \mathrm{e}$ & $7.00 \mathrm{~d}$ & $8.33 b$ & $8.00 \mathrm{bc}$ & $7.41 \mathrm{c}$ & $8.00 \mathrm{c}$ & $8.00 \mathrm{c}$ & $9.00 \mathrm{bc}$ & $9.33 \mathrm{abc}$ & $8.58 b$ \\
\hline Mean & $7.22 \mathrm{c}$ & $7.77 \mathrm{~b}$ & $8.66 \mathrm{a}$ & $8.55 \mathrm{a}$ & & $9.44 \mathrm{a}$ & $9.55 \mathrm{a}$ & $10.00 \mathrm{a}$ & $9.77 \mathrm{a}$ & \\
\hline \multicolumn{11}{|c|}{$2^{\text {nd }}$ Season 2017} \\
\hline $1.2 \mathrm{CPE}$ & 7.66ef & $8.33 \mathrm{de}$ & $9.33 \mathrm{abc}$ & $9.00 \mathrm{bcd}$ & $8.58 \mathrm{ab}$ & $11.66 \mathrm{a}$ & $12.66 \mathrm{a}$ & $11.66 \mathrm{a}$ & $11.00 \mathrm{ab}$ & $11.75 \mathrm{a}$ \\
\hline $1.0 \mathrm{CPE}$ & $8.66 \mathrm{~cd}$ & $9.00 \mathrm{bcd}$ & $10.00 \mathrm{a}$ & $9.66 \mathrm{ab}$ & $9.33 \mathrm{a}$ & $11.33 \mathrm{ab}$ & $11.33 \mathrm{ab}$ & $12.66 \mathrm{a}$ & $11.66 \mathrm{a}$ & $11.75 \mathrm{a}$ \\
\hline $0.8 \mathrm{CPE}$ & $6.66 \mathrm{~g}$ & $7.33 \mathrm{fg}$ & $8.66 \mathrm{~cd}$ & $8.33 \mathrm{de}$ & $7.75 b$ & $9.33 b$ & $9.33 b$ & $10.66 \mathrm{ab}$ & $10.66 \mathrm{ab}$ & $10.00 \mathrm{~b}$ \\
\hline Mean & $7.66 \mathrm{c}$ & $8.22 b$ & $9.33 \mathrm{a}$ & $9.00 \mathrm{a}$ & & $10.77 \mathrm{a}$ & $11.11 \mathrm{a}$ & $11.66 \mathrm{a}$ & $11.11 \mathrm{a}$ & \\
\hline \multicolumn{11}{|c|}{ Fresh weight (g/ plant) } \\
\hline $1.2 \mathrm{CPE}$ & $210.39 d$ & $213.52 \mathrm{~cd}$ & $218.14 b c$ & $222.06 b$ & $216.03 a$ & $237.42 d$ & $244.63 c$ & $254.07 \mathrm{~b}$ & $256.56 b$ & $248.17 \mathrm{a}$ \\
\hline $1.0 \mathrm{CPE}$ & $202.97 \mathrm{e}$ & $211.33 d$ & $232.33 \mathrm{a}$ & $200.88 \mathrm{e}$ & $211.88 b$ & $226.32 \mathrm{e}$ & $234.25 d$ & $275.89 a$ & $257.19 b$ & $248.41 \mathrm{a}$ \\
\hline $0.8 \mathrm{CPE}$ & $123.46 \mathrm{~h}$ & $153.61 \mathrm{~g}$ & $157.10 \mathrm{~g}$ & $178.25 f$ & $153.10 \mathrm{c}$ & $166.36 \mathrm{i}$ & $189.21 \mathrm{~h}$ & $196.53 \mathrm{~g}$ & $207.50 f$ & $189.90 \mathrm{~b}$ \\
\hline Mean & $178.94 \mathrm{c}$ & c $192.82 b$ & $202.53 \mathrm{a}$ & $200.40 \mathrm{a}$ & & $210.03 c$ & $222.70 b$ & $242.16 \mathrm{a}$ & $240.42 \mathrm{a}$ & \\
\hline \multicolumn{11}{|c|}{$2^{\text {nd }}$ Season 2017} \\
\hline $1.2 \mathrm{CPE}$ & $219.62 \mathrm{de}$ & $222.88 \mathrm{~cd}$ & $227.71 b c$ & $231.80 \mathrm{~b}$ & $225.50 \mathrm{a}$ & $249.67 d$ & $257.25 \mathrm{c}$ & $267.18 b$ & $269.81 b$ & $260.98 \mathrm{a}$ \\
\hline 1.0 CPE & $217.09 \mathrm{e}$ & $226.03 c$ & $248.50 \mathrm{a}$ & $214.85 \mathrm{e}$ & $226.62 a$ & $237.96 \mathrm{e}$ & $246.30 \mathrm{~d}$ & $290.08 \mathrm{a}$ & $270.42 b$ & $261.19 a$ \\
\hline $0.8 \mathrm{CPE}$ & $131.38 \mathrm{~h}$ & $163.47 \mathrm{~g}$ & $167.18 \mathrm{~g}$ & $189.68 \mathrm{f}$ & $162.93 b$ & $175.08 \mathrm{i}$ & $199.12 \mathrm{~h}$ & $206.83 \mathrm{~g}$ & $218.37 f$ & $199.85 b$ \\
\hline Mean & $189.36 \mathrm{c}$ & $204.13 b$ & $214.46 \mathrm{a}$ & $212.11 \mathrm{a}$ & & $220.90 c$ & $234.23 b$ & $254.70 \mathrm{a}$ & $252.87 \mathrm{a}$ & \\
\hline \multicolumn{11}{|c|}{ Dry weight (g/ plant) } \\
\hline $1.2 \mathrm{CPE}$ & $53.48 \mathrm{de}$ & $54.27 \mathrm{~cd}$ & $55.45 \mathrm{bc}$ & $56.45 b$ & $54.91 \mathrm{a}$ & $62.71 \mathrm{e}$ & $64.61 d$ & $67.11 \mathrm{c}$ & $67.77 \mathrm{c}$ & $65.55 b$ \\
\hline $1.0 \mathrm{CPE}$ & $52.73 \mathrm{e}$ & $54.90 \mathrm{c}$ & $60.36 a$ & $52.18 \mathrm{e}$ & $55.04 \mathrm{a}$ & $61.63 f$ & $63.79 d$ & $75.13 \mathrm{a}$ & $70.04 b$ & $67.65 \mathrm{a}$ \\
\hline $0.8 \mathrm{CPE}$ & $33.26 \mathrm{~h}$ & $41.38 \mathrm{~g}$ & $42.32 \mathrm{~g}$ & $48.02 \mathrm{f}$ & $41.24 b$ & $46.74 \mathrm{j}$ & $53.16 \mathrm{i}$ & $55.22 \mathrm{~h}$ & $58.30 \mathrm{~g}$ & $53.36 \mathrm{c}$ \\
\hline Mean & $46.49 \mathrm{c}$ & $50.18 \mathrm{~b}$ & $52.71 \mathrm{a}$ & $52.22 \mathrm{a}$ & & $57.03 \mathrm{c}$ & $60.52 b$ & $65.82 \mathrm{a}$ & $65.37 \mathrm{a}$ & \\
\hline \multicolumn{11}{|c|}{$2^{\text {nd }}$ Season 2017} \\
\hline $1.2 \mathrm{CPE}$ & $55.82 d$ & $56.65 \mathrm{~cd}$ & $57.88 \mathrm{bc}$ & $58.92 b$ & $57.32 b$ & $66.94 \mathrm{e}$ & $68.98 \mathrm{~d}$ & $71.64 \mathrm{c}$ & $72.34 \mathrm{c}$ & $69.98 b$ \\
\hline $1.0 \mathrm{CPE}$ & $56.40 \mathrm{~d}$ & $58.72 b$ & $64.56 a$ & $55.82 d$ & $58.87 \mathrm{a}$ & $65.28 \mathrm{f}$ & $67.57 \mathrm{e}$ & $79.58 \mathrm{a}$ & $74.18 b$ & $71.65 \mathrm{a}$ \\
\hline 0.8 CPE & $35.39 \mathrm{~g}$ & $44.03 f$ & $45.03 \mathrm{f}$ & $51.10 \mathrm{e}$ & $43.89 \mathrm{c}$ & $48.03 \mathrm{i}$ & $54.62 \mathrm{j}$ & $56.74 \mathrm{~h}$ & $59.90 \mathrm{~g}$ & $54.82 \mathrm{c}$ \\
\hline Mean & $49.20 \mathrm{c}$ & $53.14 b$ & $55.82 \mathrm{a}$ & $55.28 \mathrm{a}$ & & $60.08 \mathrm{~b}$ & $63.72 \mathrm{c}$ & $69.32 \mathrm{a}$ & $68.81 \mathrm{a}$ & \\
\hline
\end{tabular}

Means designed by the same letter at each cell are not significantly different at the $5 \%$ level according to Duncan's multiple range test.

\section{Chlorophyll content and essential oil percentage}

Chlorophyll content was improved with decreasing water irrigation in most cases for the two cuts in both seasons (Table, 2). Plants treated with 0.8 of CPE and 1.0 of CPE showed enhanced chlorophyll content in the two cuts through the two seasons without significant variation between them. Furthermore, the same treatments caused raising the essential oil $\%$ by 22 and $28 \%$ in the first cut for the two seasons and by 13.79 and $10.34 \%$ in the second one for the two seasons, respectively, as compared to 1.2 of CPE. On the other hand, essential oil \% decreased with increasing irrigation water. These findings may be due to that the supply of sufficient water from the soil might have helped in maintaining better substrate for photosynthetic activities in the leaves, carbohydrate, and essential oil. It 
is well-known that appropriate amount of moisture helps in keeping high photosynthetic rate and turgidity, which could increase the cell elongation and its multiplication at a faster rate. These results agree with other reports on black cumin by Ram et al., (2006) and Karim et al., (2017) who found that maintained soil moisture considerably enhanced essential oil yield as compared to shortage irrigation

Si NPs spraying treatments exhibited remarkable differences in chlorophyll content and essential oil\%. Spraying Si NPs (60 and $90 \mathrm{ppm})$ increased the chlorophyll content and essential oil $\%$. The increasing reached 40 and $42.86 \%$ for essential oil $\%$ in the $1^{\text {st }}$ cut during the two seasons, respectively and reached to 48.59 and $48.57 \%$ in the $2^{\text {nd }}$ cut during both seasons, respectively, over control. Increasing chlorophyll content may be attributed to that chlorophyll protected probably because of the elevated antioxidant enzyme activities that increased with Si NPs and prevented leaves chlorophyll degradation (Siddiqui and AlWhaibi, 2014). These findings were consistent with those of Kalteh et al., (2014) and Abdul Qados, (2015 ).

A significant interaction was observed between the irrigation scheduling and $\mathrm{Si} \mathrm{NPs}$ treatments on chlorophyll content and essential oil\% (Table, 2). The greatest chlorophyll content resulted from treated plants with 0.8 of CPE irrigation combined with spraying 60 ppm Si NPs. Furthermore, plants treated with 1.0 of CPE with spraying 60 ppm Si NPs recorded the greatest essential oil $\%$ of the two cuts for both seasons. These findings may be due to that increasing chlorophyll will increase the biosynthesis of the plant as were in harmony with the findings of Ram et al., (2006) and Asgharipour and Mosapour, (2016)

Table 2. Effect of irrigation scheduling and silica nanoparticles on chlorophyll content (SPAD units) and essential oil percentage of Ocimum basilicum L. during the two cuts of the two seasons of 2016 and 2017.

\begin{tabular}{|c|c|c|c|c|c|c|c|c|c|c|}
\hline \multirow{4}{*}{ Treatments } & \multicolumn{10}{|c|}{ Chlorophyll content (SPAD units) } \\
\hline & \multicolumn{10}{|c|}{$1^{\text {st }}$ Season 2016} \\
\hline & \multicolumn{5}{|c|}{$1^{\text {st }}$ cut } & \multicolumn{5}{|c|}{$2^{\text {nd }}$ cut } \\
\hline & Control & 30 ppm & 60 ppm & 90 ppm & Mean & Control & 30ppm & $60 \mathrm{ppm}$ & 90 ppm & Mean \\
\hline $1.2 \mathrm{CPE}$ & $38.18 \mathrm{c}$ & $37.32 \mathrm{c}$ & $38.32 \mathrm{c}$ & $37.64 \mathrm{c}$ & $37.86 \mathrm{~b}$ & $47.60 \mathrm{f}$ & $49.40 \mathrm{e}$ & $50.70 \mathrm{cde}$ & $51.30 \mathrm{abc}$ & $49.75 b$ \\
\hline 1.0 CPE & $39.92 \mathrm{c}$ & $41.63 \mathrm{bc}$ & $42.13 \mathrm{bc}$ & $42.66 \mathrm{abc}$ & $41.58 \mathrm{ab}$ & 49.80de & $50.60 \mathrm{cde}$ & $52.40 \mathrm{a}$ & $51.20 \mathrm{abcd}$ & $51.00 \mathrm{a}$ \\
\hline $0.8 \mathrm{CPE}$ & $37.30 \mathrm{c}$ & $38.70 \mathrm{c}$ & $48.73 \mathrm{a}$ & $47.30 \mathrm{ab}$ & $43.00 \mathrm{a}$ & $51.10 \mathrm{a}-\mathrm{d}$ & $50.90 \mathrm{bcd}$ & $52.03 \mathrm{abc}$ & $52.20 \mathrm{ab}$ & $51.55 \mathrm{a}$ \\
\hline \multirow[t]{2}{*}{ Mean } & $38.46 \mathrm{c}$ & $39.21 b c$ & 43.06 & $42.53 \mathrm{ab}$ & & $49.50 \mathrm{c}$ & $50.35 \mathrm{~b}$ & $51.73 \mathrm{a}$ & $51.58 \mathrm{a}$ & \\
\hline & \multicolumn{10}{|c|}{$2^{\text {nd }}$ Season 2017} \\
\hline $1.2 \mathrm{CPE}$ & $39.01 \mathrm{c}$ & $38.14 \mathrm{c}$ & $39.15 c$ & $38.47 \mathrm{c}$ & $38.69 \mathrm{a}$ & $47.14 d$ & $48.92 \mathrm{c}$ & $50.14 b c$ & $50.73 \mathrm{ab}$ & $49.23 b$ \\
\hline $1.0 \mathrm{CPE}$ & $40.16 \mathrm{c}$ & $41.88 b c$ & $42.38 b c$ & $42.92 b c$ & $41.83 \mathrm{ab}$ & $49.31 \mathrm{bc}$ & $50.17 \mathrm{bc}$ & $51.95 a$ & $50.7 \mathrm{ab}$ & $50.53 a$ \\
\hline $0.8 \mathrm{CPE}$ & $37.63 c$ & $39.04 c$ & $49.17 \mathrm{a}$ & $47.72 \mathrm{ab}$ & $43.39 \mathrm{a}$ & $50.74 \mathrm{ab}$ & $50.57 \mathrm{ab}$ & $51.66 \mathrm{a}$ & $51.90 \mathrm{a}$ & $51.22 \mathrm{a}$ \\
\hline \multirow[t]{2}{*}{ Mean } & $38.93 \mathrm{c}$ & $39.68 b c$ & $43.56 \mathrm{a}$ & $43.03 \mathrm{ab}$ & & $49.06 \mathrm{c}$ & $49.89 \mathrm{~b}$ & $51.25 \mathrm{a}$ & $51.11 \mathrm{a}$ & \\
\hline & \multicolumn{10}{|c|}{$\begin{array}{l}\text { Oil percentage } \\
1^{\text {st }} \text { Season } 2016\end{array}$} \\
\hline $1.2 \mathrm{CPE}$ & $0.14 \mathrm{~g}$ & $0.16 \mathrm{f}$ & $0.23 b c$ & $0.17 f$ & $0.17 \mathrm{~b}$ & $0.17 \mathrm{f}$ & $0.22 \mathrm{e}$ & $0.32 b$ & $0.28 \mathrm{c}$ & $0.25 b$ \\
\hline $1.0 \mathrm{CPE}$ & $0.14 \mathrm{~g}$ & $0.28 \mathrm{a}$ & $0.29 \mathrm{a}$ & $0.18 \mathrm{ef}$ & $0.22 \mathrm{a}$ & $0.19 \mathrm{f}$ & $0.24 \mathrm{de}$ & $0.37 \mathrm{a}$ & $0.34 \mathrm{ab}$ & $0.29 a$ \\
\hline $0.8 \mathrm{CPE}$ & $0.16 \mathrm{f}$ & $0.21 \mathrm{~cd}$ & $0.25 b$ & $0.19 \mathrm{de}$ & $0.20 \mathrm{a}$ & $0.18 \mathrm{f}$ & $0.26 \mathrm{~cd}$ & $0.33 b$ & $0.34 \mathrm{~b}$ & $0.28 \mathrm{a}$ \\
\hline \multirow[t]{2}{*}{ Mean } & $0.15 \mathrm{~d}$ & $0.22 \mathrm{~b}$ & $0.25 \mathrm{a}$ & $0.18 \mathrm{c}$ & & $0.18 \mathrm{~d}$ & $0.24 \mathrm{c}$ & $0.34 \mathrm{a}$ & $0.32 b$ & \\
\hline & \multicolumn{10}{|c|}{$2^{\text {nd }}$ Season 2017} \\
\hline $1.2 \mathrm{CPE}$ & $0.14 h$ & $0.17 \mathrm{fg}$ & $0.24 \mathrm{c}$ & $0.18 \mathrm{efg}$ & $0.18 b$ & $0.18 \mathrm{f}$ & $0.23 \mathrm{e}$ & $0.33 b$ & $0.29 \mathrm{c}$ & $0.26 \mathrm{~b}$ \\
\hline 1.0 CPE & $0.16 \mathrm{gh}$ & $0.32 \mathrm{a}$ & $0.33 \mathrm{a}$ & $0.20 \mathrm{de}$ & $0.25 \mathrm{a}$ & $0.19 \mathrm{f}$ & $0.25 \mathrm{de}$ & $0.38 \mathrm{a}$ & $0.35 \mathrm{ab}$ & $0.29 a$ \\
\hline $0.8 \mathrm{CPE}$ & $0.19 \mathrm{ef}$ & $0.23 \mathrm{c}$ & $0.28 b$ & $0.22 \mathrm{~cd}$ & $0.23 \mathrm{a}$ & $0.18 \mathrm{f}$ & $0.27 \mathrm{~cd}$ & $0.33 b$ & $0.34 b$ & $0.28 \mathrm{ab}$ \\
\hline Mean & $0.16 \mathrm{~d}$ & $0.24 b$ & $0.28 \mathrm{a}$ & $0.20 \mathrm{c}$ & & $0.18 \mathrm{~d}$ & $0.25 \mathrm{c}$ & $0.35 \mathrm{a}$ & $0.33 b$ & \\
\hline
\end{tabular}

Means designed by the same letter at each cell are not significantly different at the $5 \%$ level according to Duncan's multiple range test.

\section{Stomatal resistance and transpiration rate}

Stomatal resistance values significantly increased by decreasing water irrigation level in both cuts for the two seasons (Table, 3 ) which, elevated in plants under water deficit circumstances ( 0.8 of CPE) in the two cuts during the two seasons. Correspondingly, a decline in transpiration rate was noticed in the plants subjected to a water deficit. The least stomatal resistance values and highest values of transpiration rate resulted from plants under 1.2 of CPE treatment. These means that water deficit decreased the transpiration rate which is linked to a stomatal mechanism, because the stomata are normally closed under water limited conditions (Pereira et al., 2006). These results could assume the acting of physiological mechanisms under water deficit conditions and resistance to water loss and causes improved adaptation to drought for the more superficial root system. In these conditions, it is anticipated that the partial stomatal closure, with the purpose of restraining the water vapor loss and decreasing the energy loss by transpiration, may also restrain the $\mathrm{CO}_{2}$ entrance, resulting in water economy and reduction of defoliation (De Sen et al., 2007).

Spraying plants with $\mathrm{Si}$ NPs initiated a significant enhancement in stomatal resistance values and a significant reduction in transpiration rate. Accordingly, the highest stomatal resistance values were recorded under spraying of $90 \mathrm{ppm} \mathrm{Si} \mathrm{NPs} \mathrm{and} \mathrm{the}$ same concentration lessened transpiration rate, Moreover the low-silicon concentrations reduced also 
water loss from basil plants. This may be due to that $\mathrm{Si}$ influences stomata movement causing the formation of a double layer of cuticular silicon. Depending on its thickness therefore, the double layer also decreases the transpiration rate via the stomata (Ma et al., 2001 and Gao et al., 2006). According to Karmollachaab et al., (2014) application of Si NPs caused water shortage tolerance by reducing transpiration rate.

The transpiration rates were reduced with decreasing irrigation levels from 1.2 of CPE to 0.8 of CPE nevertheless, increasing silicon levels alleviated the effects of decreasing water levels therefore, increasing water retention in the water-deficient plants. In addition, silicon accumulation in the cell wall reduced water loss as transpiration, and silicon improved the water utilization of the soil, likely due to a reduction in evapotranspiration. The increasing in stomatal resistance under water shortage may be due to a decline in stomatal conductance which was connected with water availability, and the water potential results proved these data. An increase in silicon concentrations decreases these effects as a result of silicon deposition in the epidermal walls of the leaves (Pereira et al., 2006 and Asgharipour and Mosapour, 2016).

Table 3. Effect of irrigation scheduling and silica nanoparticles on stomatal resistance (s/cm) and transpiration rate $\left(\mu \mathrm{gH}_{2} \mathrm{o} / \mathrm{cm}^{-2} \mathrm{~s}^{-1}\right)$ of Ocimum basilicum $\mathrm{L}$. during the two cuts of the two seasons of 2016 and 2017.

\begin{tabular}{|c|c|c|c|c|c|c|c|c|c|c|}
\hline \multirow{4}{*}{ Treatments } & \multicolumn{10}{|c|}{ Stomatal resistance $(\mathrm{s} / \mathrm{cm})$} \\
\hline & \multicolumn{10}{|c|}{$1^{\text {st }}$ Season 2016} \\
\hline & \multicolumn{5}{|c|}{$1^{\text {st }}$ cut } & \multicolumn{5}{|c|}{$2^{\text {nd }}$ cut } \\
\hline & Control & 30 ppm & $60 \mathrm{ppm}$ & 90 ppm & Mean & Control & 30ppm & $60 \mathrm{ppm}$ & 90 ppm & Mean \\
\hline $1.2 \mathrm{CPE}$ & 1.391 & $1.42 \mathrm{k}$ & $1.91 \mathrm{j}$ & $2.17 \mathrm{i}$ & $1.72 \mathrm{c}$ & $1.26 \mathrm{j}$ & $1.29 \mathrm{j}$ & $1.76 \mathrm{i}$ & $2.24 \mathrm{~h}$ & $1.63 \mathrm{c}$ \\
\hline $1.0 \mathrm{CPE}$ & $2.33 \mathrm{~h}$ & $2.39 \mathrm{~g}$ & $2.72 \mathrm{f}$ & $3.16 \mathrm{e}$ & $2.65 b$ & $2.63 \mathrm{f}$ & $2.32 \mathrm{~g}$ & $2.64 \mathrm{f}$ & $3.12 \mathrm{e}$ & $2.67 \mathrm{~b}$ \\
\hline $0.8 \mathrm{CPE}$ & $3.72 \mathrm{a}$ & $3.56 \mathrm{~b}$ & $3.43 \mathrm{c}$ & $3.24 \mathrm{~d}$ & $3.48 \mathrm{a}$ & $3.80 \mathrm{a}$ & $3.61 \mathrm{~b}$ & $3.40 \mathrm{c}$ & $3.35 \mathrm{~d}$ & $3.54 \mathrm{a}$ \\
\hline \multirow[t]{2}{*}{ Mean } & $2.48 \mathrm{c}$ & $2.45 \mathrm{~d}$ & $2.68 \mathrm{~b}$ & $2.85 \mathrm{a}$ & & $2.56 \mathrm{c}$ & $2.40 \mathrm{~d}$ & $2.60 \mathrm{~b}$ & $2.90 \mathrm{a}$ & \\
\hline & \multicolumn{10}{|c|}{$2^{\text {nd }}$ Season 2017} \\
\hline $1.2 \mathrm{CPE}$ & $1.37 \mathrm{~g}$ & $1.40 \mathrm{~g}$ & $1.93 \mathrm{f}$ & $2.20 \mathrm{ef}$ & $1.72 \mathrm{c}$ & $1.24 \mathrm{j}$ & $1.27 \mathrm{j}$ & $1.74 \mathrm{i}$ & $2.21 \mathrm{~h}$ & $1.61 \mathrm{c}$ \\
\hline 1.0 CPE & $2.36 \mathrm{e}$ & $2.42 \mathrm{e}$ & $2.82 \mathrm{~d}$ & $3.20 \mathrm{c}$ & $2.7 \mathrm{~b}$ & $2.60 \mathrm{f}$ & $2.29 \mathrm{~g}$ & $2.61 \mathrm{f}$ & $3.10 \mathrm{e}$ & $2.65 b$ \\
\hline $0.8 \mathrm{CPE}$ & $3.69 \mathrm{a}$ & $3.54 \mathrm{ab}$ & $3.74 \mathrm{a}$ & $3.27 b c$ & $3.56 \mathrm{a}$ & $3.77 \mathrm{a}$ & $3.54 \mathrm{~b}$ & $3.36 \mathrm{c}$ & $3.31 \mathrm{~d}$ & $3.49 \mathrm{a}$ \\
\hline \multirow[t]{2}{*}{ Mean } & $2.47 \mathrm{~b}$ & $2.45 \mathrm{~b}$ & $2.83 \mathrm{a}$ & $2.89 \mathrm{a}$ & & $2.53 \mathrm{~d}$ & $2.37 \mathrm{c}$ & $2.57 \mathrm{~b}$ & $2.87 \mathrm{a}$ & \\
\hline & \multicolumn{10}{|c|}{ Transpiration rate $\left(\mu \mathrm{gH}_{2} \mathrm{O} / \mathrm{cm}^{-2} \mathrm{~s}^{-1}\right)$} \\
\hline $1.2 \mathrm{CPE}$ & $4.44 a$ & $4.31 \mathrm{a}$ & $3.51 \mathrm{bc}$ & $3.23 \mathrm{~cd}$ & $3.87 \mathrm{a}$ & $4.12 \mathrm{a}$ & $4.00 \mathrm{~b}$ & $3.77 \mathrm{c}$ & $3.17 \mathrm{de}$ & $3.76 \mathrm{a}$ \\
\hline $1.0 \mathrm{CPE}$ & $3.78 \mathrm{~b}$ & $3.21 \mathrm{~d}$ & $2.84 \mathrm{e}$ & $2.31 \mathrm{f}$ & $3.03 \mathrm{~b}$ & $3.21 \mathrm{~d}$ & $3.13 \mathrm{e}$ & $2.99 \mathrm{f}$ & $2.85 \mathrm{~g}$ & $3.04 \mathrm{~b}$ \\
\hline 0.8 CPE & $2.14 \mathrm{f}$ & $2.21 \mathrm{f}$ & $2.39 \mathrm{f}$ & $2.77 \mathrm{e}$ & $2.37 \mathrm{c}$ & $2.21 \mathrm{k}$ & $2.35 \mathrm{j}$ & $2.48 \mathrm{i}$ & $2.69 \mathrm{~h}$ & $2.43 c$ \\
\hline \multirow[t]{2}{*}{ Mean } & $3.45 \mathrm{a}$ & $3.24 b$ & $2.91 \mathrm{c}$ & $2.77 \mathrm{c}$ & & $3.18 \mathrm{a}$ & $3.16 \mathrm{a}$ & $3.08 \mathrm{~b}$ & $2.90 \mathrm{c}$ & \\
\hline & \multicolumn{10}{|c|}{$2^{\text {nd }}$ Season 2017} \\
\hline $1.2 \mathrm{CPE}$ & $4.31 \mathrm{a}$ & $4.28 b$ & $3.47 \mathrm{c}$ & $3.20 \mathrm{e}$ & $3.81 \mathrm{a}$ & $4.14 \mathrm{a}$ & $4.04 b$ & $3.79 \mathrm{c}$ & $3.19 \mathrm{~d}$ & $3.79 \mathrm{a}$ \\
\hline $1.0 \mathrm{CPE}$ & $3.42 \mathrm{~d}$ & $3.19 \mathrm{f}$ & $2.80 \mathrm{~g}$ & $2.28 \mathrm{j}$ & $2.92 b$ & $3.19 \mathrm{~d}$ & $3.15 \mathrm{e}$ & $3.01 \mathrm{f}$ & $2.88 \mathrm{~g}$ & $3.05 \mathrm{~b}$ \\
\hline $0.8 \mathrm{CPE}$ & 2.131 & $2.20 \mathrm{k}$ & $2.38 \mathrm{i}$ & $2.76 \mathrm{~h}$ & $2.36 \mathrm{c}$ & $2.22 \mathrm{k}$ & $2.34 \mathrm{j}$ & $2.46 \mathrm{i}$ & $2.72 \mathrm{~h}$ & $2.43 \mathrm{c}$ \\
\hline Mean & $3.28 \mathrm{a}$ & $3.22 b$ & $2.88 \mathrm{c}$ & $2.74 \mathrm{~d}$ & & $3.18 \mathrm{a}$ & $3.17 \mathrm{~b}$ & $3.08 \mathrm{c}$ & $2.93 \mathrm{~d}$ & \\
\hline
\end{tabular}

Means designed by the same letter at each cell are not significantly different at the $5 \%$ level according to Duncan's multiple range test.

\section{Essential oil constituents}

The results of gas chromatography analysis indicated that the identified components of volatile oil were $\alpha$-pinene, $\beta$-pinene, 1,8 cineole, linalool, $\alpha-$ terpineol, geranyl acetate, methyl chavicol, $\beta$ caryophyllene (Table, 4). The most abundant components were $\alpha$-terpineol and linalool in plants sprayed with 60 and 90 ppm Si NPs under all irrigation treatments but 1,8 cineole appeared at $30 \mathrm{ppm}$ Si NPs with 0.8 of CPE. The minimum content was recorded with $\alpha$-pinene under all treatments. These results were confirmed by raised photosynthetic activity in the treated plants with $\mathrm{Si}$ NPs related to secondary metabolites positively synthesised (Letchamo et al., 1999). These results are in agreement with Singh, (2002) and Gao, (2015).

\section{Yield characters}

Optimum irrigation (1.0 of CPE) is essential to obtain the highest fresh and oil yield $\mathrm{ha}^{-1}$ without a significant difference with 1.2 of CPE for fresh yield in the two cuts during both seasons (Table, 5). Moreover, low fresh and oil yield ha ${ }^{-1}$ were recorded from plants growing under 0.8 of CPE. It is noteworthy that always essential oil cannot be increased along with increases in water stress, because assimilates produce osmotic regulators such as soluble sugars and proline in severe water stress (Munns and Tester, 2008). Similarly, (Letchamo et al.., 1999) found that biosynthesis of medicinal and aromatic plants secondary metabolites positively associated to the photosynthesis and negatively to the respiration.

The yield of the above-mentioned traits in the plants differed significantly as a result of Si NPs spraying. Fresh and oil yield $\mathrm{ha}^{-1}$ were increased with increasing the concentration of Si NPs spraying, and the greatest fresh yield $\mathrm{ha}^{-1}$ was obtained from plants sprayed with 60 and $90 \mathrm{ppm}$ of $\mathrm{Si}$ NPs without significant differences between them. On the other hand, plants sprayed with $60 \mathrm{ppm} \mathrm{Si}$ NPs raised oil yield $\mathrm{ha}^{-1}$ by 52.2 and $52.21 \%$ for both cuts in both 
seasons, respectively. Increasing yield resulted from Si application could be due to increased leaf chlorophyll content, yield attributes, and photosynthetically active area. A positive influence of Si on crop yield has been reported by Silva et al., (2012) on tomato.

Significant variations were detected between the interaction of irrigation scheduling and silica nanoparticles treatments on fresh and oil yield $\mathrm{ha}^{-1}$
(Table, 5). Silica nanoparticles spraying enhanced fresh and oil yield $\mathrm{ha}^{-1}$ under 1.0 of CPE compared with control. The highest fresh and oil yield $\mathrm{ha}^{-1}$ were recorded from the plants irrigated with 1.0 of CPE and sprayed with Si NPs (60 ppm) in the two cuts for both seasons. These findings were in line with earlier reports of Ekren et al., (2012) on basil and Sodaeizadeh and Mansouri, (2014) on Salvia macrosiphon.

Table 4. Effect of irrigation scheduling and silica nanoparticles treatments on essential oil components of Ocimum basilicum L. during the second season 2017.

\begin{tabular}{|c|c|c|c|c|c|c|c|}
\hline \multirow{3}{*}{$\begin{array}{l}\text { Treatments } \\
\text { Components }\end{array}$} & \multicolumn{2}{|c|}{$1.2 \mathrm{CPE}$} & \multicolumn{2}{|c|}{ 1.0 CPE } & \multicolumn{3}{|c|}{ 0.8 CPE } \\
\hline & Si NPs & Si NPs & Si NPs & Si NPs & Si NPs & Si NPs & Si NPs \\
\hline & $60 \mathrm{ppm}$ & 90 ppm & 60 ppm & 90 ppm & 30 ppm & 60 ppm & 90 ppm \\
\hline$\alpha$-pinene & 0.16 & 0.31 & 0.62 & - & 0.05 & 0.24 & 0.20 \\
\hline$\beta$-pinene & 0.47 & 0.47 & 0.91 & 0.39 & 0.11 & 0.41 & 0.53 \\
\hline 1,8 cineole & 5.05 & 5.83 & 9.31 & 4.17 & 86.20 & 8.23 & 4.40 \\
\hline Linalool & 31.14 & 29.93 & 31.80 & 29.57 & 5.55 & 39.98 & 31.43 \\
\hline$\alpha$-Terpineol & 42.28 & 33.77 & 38.15 & 48.04 & 4.77 & 10.84 & 35.39 \\
\hline Geranyl acetate & 2.04 & 2.10 & 0.81 & 2.63 & 0.32 & 2.43 & 2.07 \\
\hline Methyl chavicole & 0.48 & 2.86 & 3.01 & 1.00 & 0.25 & 0.23 & 1.37 \\
\hline$\beta$-caryophyllene & 5.38 & 7.75 & 8.46 & 4.58 & 0.87 & 14.20 & 6.75 \\
\hline
\end{tabular}

Table 5. Effect of irrigation scheduling and silica nanoparticles on fresh yield $\left(\mathrm{t} \mathrm{ha}^{-1}\right)$ and oil yield $\left(1 \mathrm{ha}^{-1}\right)$ for $^{-1}$ both cuts of Ocimum basilicum L. during the two seasons of 2016 and 2017.

\begin{tabular}{|c|c|c|c|c|c|c|c|c|c|c|}
\hline \multirow{4}{*}{ Treatments } & \multicolumn{10}{|c|}{ Fresh yield $\left(\mathrm{t} \mathrm{ha}^{-1}\right)$} \\
\hline & \multicolumn{10}{|c|}{$1^{\text {st }}$ Season 2016} \\
\hline & \multicolumn{5}{|c|}{$1^{\text {st }}$ cut } & \multicolumn{5}{|c|}{$2^{\text {nd }}$ cut } \\
\hline & Control & 30 ppm & 60 ppm & 90 ppm & Mean & Control & 30ppm & 60 ppm & 90 ppm & Mean \\
\hline $1.2 \mathrm{CPE}$ & $12.23 \mathrm{~d}$ & $12.38 \mathrm{~cd}$ & $12.65 \mathrm{c}$ & $12.94 \mathrm{~b}$ & $12.55 \mathrm{a}$ & $13.80 \mathrm{e}$ & $14.18 d$ & $14.73 \mathrm{c}$ & $14.95 b c$ & $14.42 \mathrm{a}$ \\
\hline $1.0 \mathrm{CPE}$ & $11.86 \mathrm{e}$ & $12.34 \mathrm{~d}$ & $13.57 \mathrm{a}$ & $11.73 \mathrm{e}$ & $12.38 \mathrm{a}$ & $13.22 \mathrm{f}$ & $13.68 \mathrm{e}$ & $16.12 \mathrm{a}$ & $15.03 \mathrm{~b}$ & $14.51 \mathrm{a}$ \\
\hline $0.8 \mathrm{CPE}$ & $7.38 \mathrm{~h}$ & $9.18 \mathrm{~g}$ & $9.39 \mathrm{~g}$ & $10.65 f$ & $9.15 b$ & $9.94 j$ & $11.31 \mathrm{i}$ & $11.75 \mathrm{~h}$ & $12.40 \mathrm{~g}$ & $11.35 \mathrm{~b}$ \\
\hline Mean & $10.49 \mathrm{c}$ & $11.30 \mathrm{~b}$ & $11.87 \mathrm{a}$ & $11.78 \mathrm{a}$ & & $12.32 \mathrm{c}$ & $13.06 \mathrm{~b}$ & $14.20 \mathrm{a}$ & $14.13 \mathrm{a}$ & \\
\hline & \multicolumn{10}{|c|}{$2^{\text {nd }}$ Season 2017} \\
\hline $1.2 \mathrm{CPE}$ & $12.77 \mathrm{de}$ & $12.92 \mathrm{~cd}$ & $13.20 b c$ & $13.51 b$ & $13.10 \mathrm{a}$ & $14.51 \mathrm{e}$ & $14.92 \mathrm{~d}$ & $15.49 \mathrm{c}$ & $15.72 b c$ & $15.16 \mathrm{a}$ \\
\hline $1.0 \mathrm{CPE}$ & $12.68 \mathrm{de}$ & $13.20 \mathrm{bc}$ & $14.52 \mathrm{a}$ & $12.55 \mathrm{e}$ & $13.24 \mathrm{a}$ & $13.90 \mathrm{f}$ & $14.39 \mathrm{e}$ & $16.95 \mathrm{a}$ & $15.80 \mathrm{~b}$ & $15.26 \mathrm{a}$ \\
\hline $0.8 \mathrm{CPE}$ & $7.85 \mathrm{~h}$ & $9.77 \mathrm{~g}$ & $9.99 \mathrm{~g}$ & $11.34 \mathrm{f}$ & $9.74 b$ & $10.47 \mathrm{j}$ & $11.90 \mathrm{i}$ & $12.36 \mathrm{~h}$ & $13.05 \mathrm{~g}$ & $11.91 \mathrm{~b}$ \\
\hline Mean & $11.10 \mathrm{c}$ & $11.97 \mathrm{~b}$ & $12.57 \mathrm{a}$ & $12.47 \mathrm{a}$ & & $12.96 \mathrm{c}$ & $13.74 b$ & $14.93 \mathrm{a}$ & $14.86 \mathrm{a}$ & \\
\hline \multicolumn{11}{|c|}{ Oil yield $1 \mathrm{ha}^{-1}$ (both cuts) } \\
\hline & \multicolumn{5}{|c|}{$1^{\text {st }}$ Season 2016} & \multicolumn{5}{|c|}{$2^{\text {nd }}$ Season 2017} \\
\hline 1.2 CPE & $41.14 \mathrm{~g}$ & $52.45 f$ & $76.98 \mathrm{~b}$ & $65.12 \mathrm{de}$ & $58.92 b$ & $45.21 \mathrm{e}$ & $57.61 d$ & $84.53 b$ & $71.44 \mathrm{c}$ & $64.70 b$ \\
\hline 1.0 CPE & $42.74 \mathrm{~g}$ & $69.30 \mathrm{~cd}$ & $100.01 \mathrm{a}$ & $73.32 \mathrm{bc}$ & $71.34 \mathrm{a}$ & $48.20 \mathrm{e}$ & $79.17 b$ & $112.82 \mathrm{a}$ & $81.68 b$ & $80.47 \mathrm{a}$ \\
\hline $0.8 \mathrm{CPE}$ & $30.89 \mathrm{~h}$ & 49.70f & $63.15 \mathrm{e}$ & $63.21 \mathrm{e}$ & $51.74 \mathrm{c}$ & $34.66 \mathrm{f}$ & $55.66 \mathrm{~d}$ & $70.60 \mathrm{c}$ & $70.25 \mathrm{c}$ & $57.79 \mathrm{c}$ \\
\hline Mean & $38.26 \mathrm{~d}$ & $57.15 \mathrm{c}$ & $80.05 \mathrm{a}$ & $67.22 \mathrm{~b}$ & & $42.69 d$ & $64.14 \mathrm{c}$ & $89.32 \mathrm{a}$ & $74.46 \mathrm{~b}$ & \\
\hline
\end{tabular}

Means designed by the same letter at each cell are not significantly different at the $5 \%$ level according to Duncan's multiple range test.

Water consumptive use and applied irrigation water

There are visible differences of water consumptive use and applied irrigation water between the different irrigation treatments for basil plant (Table, 6). The highest values of seasonal consumptive use and applied irrigation water were obtained for 1.2 of CPE treatment, while the lowest values were found for 0.8 of $\mathrm{CPE}$ as the mean of both growing seasons. Water consumptive use of basil plant decreased after 1.0 of CPE and 0.8 of CPE by $6 \%$ and $23.9 \%$ compared to 1.2 of CPE as the mean of two growing seasons, while, the decreases of applied irrigation water after 1.0 of CPE and 0.8 of CPE were $3.3 \%$ and $22.9 \%$ as the mean of both growing seasons compared to 1.2 of $\mathrm{CPE}$. This result agrees with those obtained by Ram et al, (1994) and Ram et al., (2006) as they indicated that irrigation when the cumulate higher coefficient of CPE, means that applied a higher amount of irrigation water. Gao, (2015) stated that cultivating basil under deficit irrigation can reduce water applied.

There are slight differences in water consumptive use between the different silica nanoparticles treatments and it takes the descending order control $>30 \mathrm{ppm}>60$ ppm $>90$ ppm. However, there are no obvious differences of applied irrigation water between the different silica nanoparticles treatments as mean of the two growing seasons (Table, 6). 
Table 6. The monthly, seasonal consumptive use and applied irrigation water as influenced by irrigation scheduling and silica nanoparticles treatments as a mean of 2016 and 2017 growing seasons.

\begin{tabular}{|c|c|c|c|c|c|c|c|c|c|}
\hline \multirow{2}{*}{\multicolumn{2}{|c|}{ Treatments }} & \multicolumn{6}{|c|}{ Monthly water consumptive use (cm) } & \multirow{2}{*}{$\begin{array}{c}\text { Seasonal } \\
\text { rates }(\mathrm{cm})\end{array}$} & \multirow{2}{*}{$\begin{array}{c}\text { Water } \\
\text { applied }(\mathrm{cm})\end{array}$} \\
\hline & & April & May & June & July & Aug. & Sep. & & \\
\hline & Control & 2.09 & 7.38 & 14.50 & 13.07 & 12.35 & 7.42 & 56.81 & 66.88 \\
\hline 1.2 & $30 \mathrm{ppm}$ & 2.09 & 7.35 & 14.47 & 12.98 & 12.22 & 7.37 & 56.48 & 66.21 \\
\hline \multirow[t]{2}{*}{$\mathrm{CPE}$} & $60 \mathrm{ppm}$ & 2.09 & 7.22 & 14.33 & 12.92 & 12.16 & 7.33 & 56.05 & 65.97 \\
\hline & $90 \mathrm{ppm}$ & 2.09 & 7.18 & 14.29 & 12.87 & 12.11 & 7.30 & 55.84 & 65.76 \\
\hline \multicolumn{2}{|l|}{ Mean } & 2.09 & 7.28 & 14.40 & 12.96 & 12.21 & 7.36 & 56.30 & 66.21 \\
\hline & Control & 2.09 & 7.24 & 14.02 & 11.63 & 11.06 & 7.29 & 53.33 & 64.53 \\
\hline 1.0 & 30 ppm & 2.09 & 7.20 & 13.94 & 11.57 & 10.94 & 7.24 & 52.98 & 64.10 \\
\hline \multirow{2}{*}{$\mathrm{CPE}$} & $60 \mathrm{ppm}$ & 2.09 & 7.15 & 13.85 & 11.56 & 10.89 & 7.19 & 52.73 & 63.80 \\
\hline & 90 ppm & 2.09 & 7.14 & 13.83 & 11.52 & 10.87 & 7.18 & 52.63 & 63.68 \\
\hline \multicolumn{2}{|l|}{ Mean } & 2.09 & 7.18 & 13.91 & 11.57 & 10.94 & 7.23 & 52.92 & 64.03 \\
\hline & Control & 2.09 & 5.93 & 10.86 & 9.25 & 8.71 & 6.44 & 43.28 & 51.76 \\
\hline 0.8 & 30 ppm & 2.09 & 5.88 & 10.77 & 9.16 & 8.68 & 6.37 & 42.95 & 51.01 \\
\hline \multirow[t]{2}{*}{ CPE } & $60 \mathrm{ppm}$ & 2.09 & 5.85 & 10.74 & 9.08 & 8.64 & 6.32 & 42.72 & 50.93 \\
\hline & 90 ppm & 2.09 & 5.81 & 10.70 & 9.05 & 8.60 & 6.29 & 42.54 & 50.54 \\
\hline Mean & & 2.09 & 5.87 & 10.77 & 9.14 & 8.66 & 6.36 & 42.87 & 51.06 \\
\hline \multicolumn{2}{|c|}{ Consumptive use mean $(\mathrm{cm})$} & Contro & $=51.14$ & $30 \mathrm{ppr}$ & 50.80 & $60 \mathrm{pl}$ & 50.50 & \multicolumn{2}{|c|}{$90 \mathrm{ppm}=50.34$} \\
\hline
\end{tabular}

Productivity of irrigation water (PIW) and water productivity (WP)

There were significant differences of PIW and WP between the different irrigation treatments (Fig 1 and 2). The maximum values of PIW and WP were recorded from 1.0 of $\mathrm{CPE}$ compared to other irrigation treatments as the mean of both growing seasons. This may be due to the higher herb yield because of maintained soil moisture. Water shortage decreases turgidity, which causes a reduction in both growth and cell development, particularly in the leaves and stems (Shao et al., 2008). The values of PIW and WP after the different silica nanoparticles treatments had the descending order $90 \mathrm{ppm}>60 \mathrm{ppm}>30 \mathrm{ppm}>\mathrm{C}$, while there were no considerable differences of PIW and WP values between $90 \mathrm{ppm}$ and $60 \mathrm{ppm}$ silica nanoparticles treatments as mean of the two growing seasons.
There were significant differences of PIW and WP between the different interactions of irrigation and silica nanoparticles. The highest values of PIW and WP were achieved from 1.0 of CPE with 60 ppm Si NPs, while the lowest values of PIW and WP were obtained from 0.8 of CPE with control (spring with distilled water) as mean of the two growing seasons. The values of PIW and WP of 1.0 of CPE with 60 ppm Si NPs silicon nanoparticles increased by 20 and $24 \%$, respectively compared to 1.2 of CPE with control as the mean of both growing seasons. This may be due to the amount of applied irrigation water, when applied irrigation water decreases water productivity increases Kamkar et al., (2011) on canola and Hassan and Ali, (2014) on coriander. With increasing the ratio of applied irrigation water to $\mathrm{CPE}$, water productivity decreases (Singh, 2002).

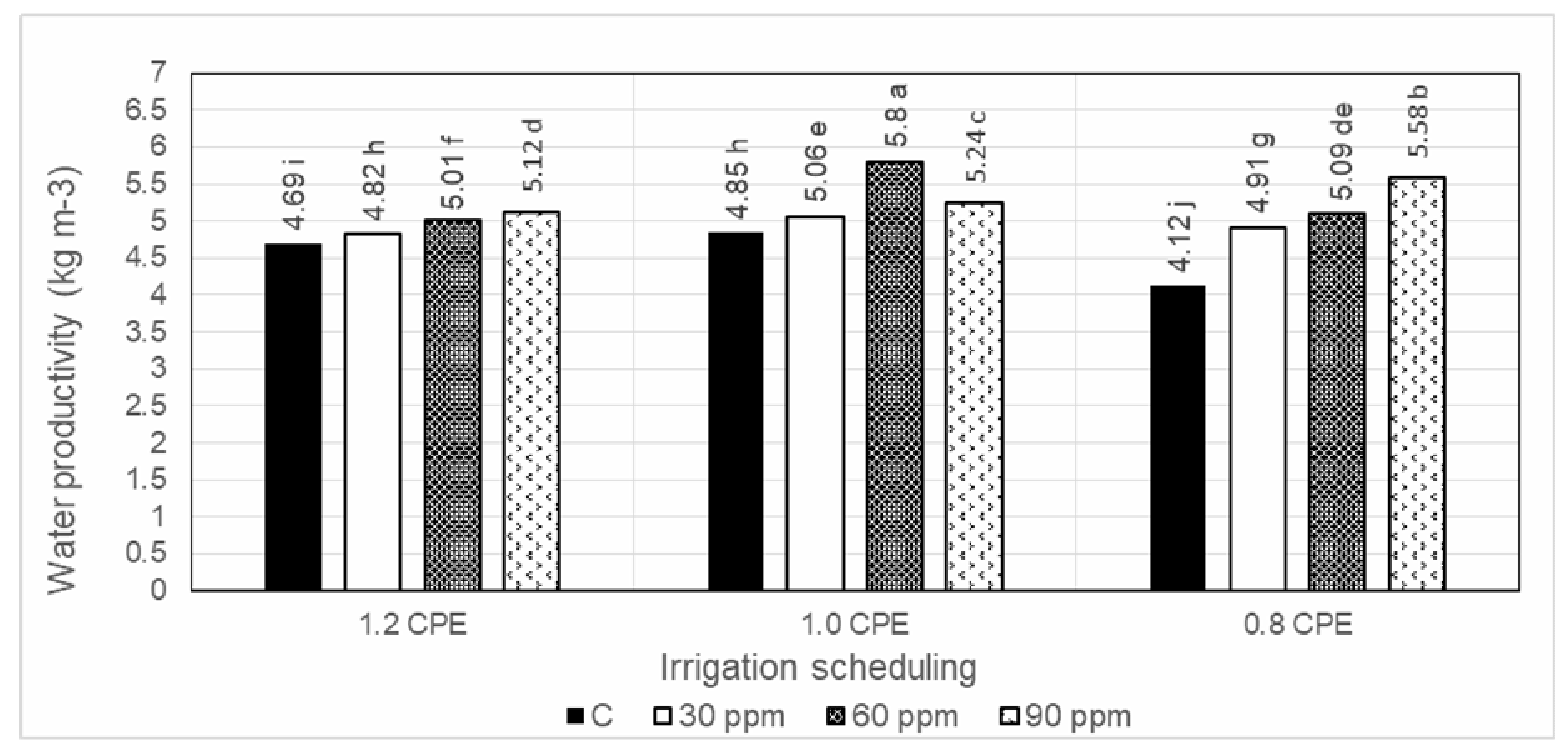

Fig. 1. Effect of irrigation and silica nanoparticles on water productivity of basil plant. 


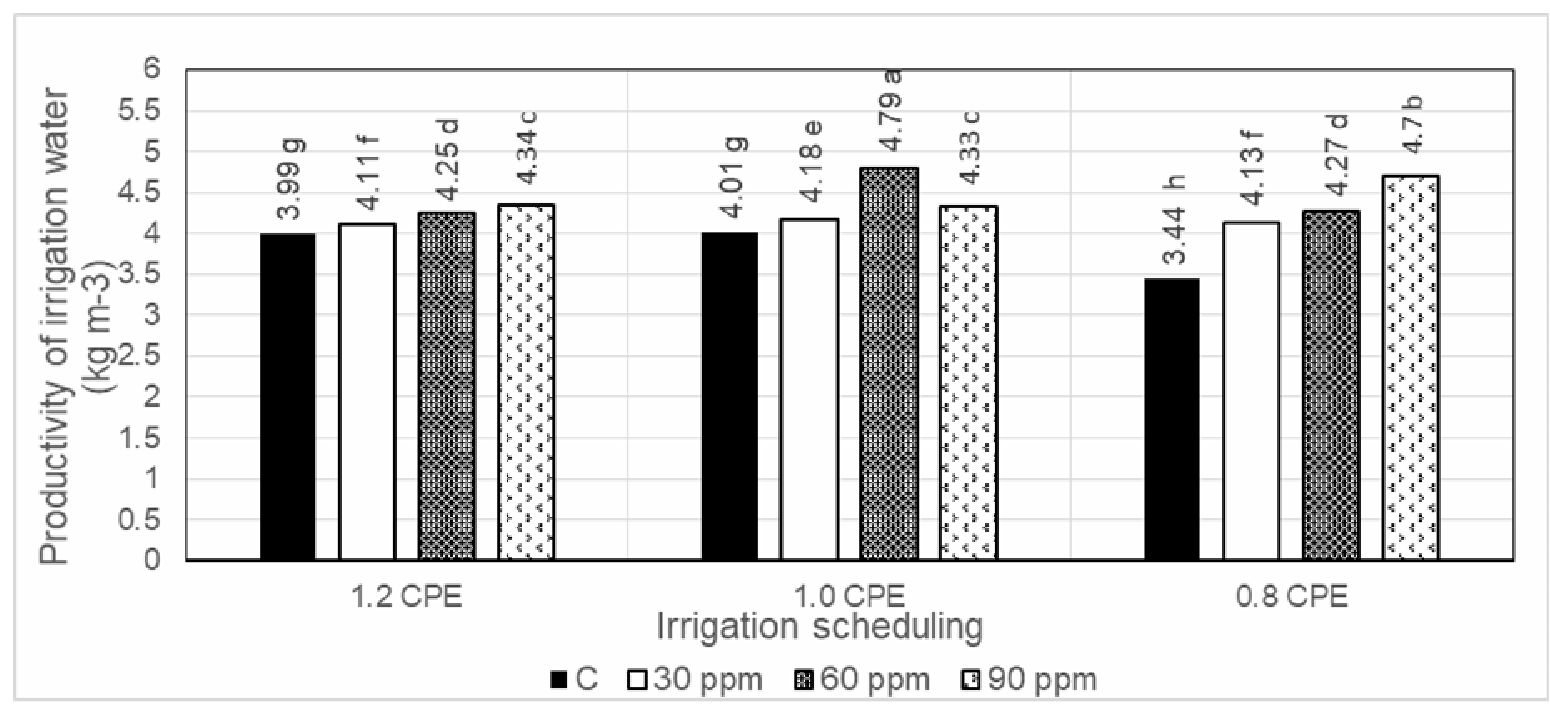

Fig 2. Effect of irrigation and silica nanoparticles on productivity of irrigation water for basil plant.

\section{CONCLUSION}

Under the study conditions it could be concluded that irrigation of Ocimum basilicum L. plants when cumulates 1.0 from pan evaporation (1.0 of CPE) with spraying silica NPs $60 \mathrm{ppm}$ twice one month before each cut, this will enhance growth, fresh and oil yield, stomatal resistance, oil component and decrease transpiration rate. Moreover, it decreases water consumptive use by $7 \%$ and applied irrigation water by $5 \%$ while, it increases water productivity by $24 \%$ and productivity of irrigation water by $20 \%$, respectively compared to irrigation with 1.2 of CPE without spraying silica NPs.

\section{REFERENCES}

Abdul Qados, A. M. S. (2015) Mechanism of nanosilicon-mediated alleviation of salinity stress in faba bean (Vicia faba L.) plants. American J. Experim. Agric., 7(2): 78-95.

Ahmed, M.; M. Asif and F. Hassan (2014).Augmenting drought tolerance in sorghum by silicon nutrition. Acta Physiol. Plant.,36 (2):473-483.

Ali, M.H.; M.R. Hoque; A.A. Hassan and A. Khair (2007). Effects of deficit irrigation on yield, water productivity, and economic returns of wheat. Agric. Water Manag. 92: 151-161.

Alishah, H. M. ; R. Heidari, A. Hassani, and A. A. Dizaji (2006). Effect of water stress on some morphological and biochemical characteristics of purple basil (Ocimum basilicum), J. Bio. Sci., 6 (4): 763-767.

Asgharipour, M. R. and H.Mosapour (2016) A foliar application silicon enchances drought tolerance in fennel. J. Animal \& Plant Sci., 26 (4):10561062.

British Parmacopoeia (1963). Determination of Volatile Oil in Drugs. The Pharmaceutical Press, London.
Brunauer, S. (1945). The Adsorption of Gases and Vapors, vol. 1, Princeton University Press, Princeton, NJ.

Cote-Beaulieu, C.; F.Chain ; J.G. Menzies; S.D. Kinrade and R.R. Bélanger (2009). Absorption of aqueous inorganic and organic silicon compounds by wheat and their effect on growth and powdery mildew control. Environ. Exp. Bot., 65: 155-161.

Delfine, S.; F. Loreto; P. Pinelli; R. Tognetti and A. Alvino (2005). Isoprenoids content and photosynthetic limitations in rosemary and spearmint plants under water stress. Agric. Ecosyst. Environ.,106 (2):243-252.

De Sen, J. O. A.; H.A. Zaidan and P. R. D.C. Castro (2007). Transpiration and stomatal resistance variations of perennial tropical crops under soil water availability conditions and water deficit. Braz. Arch. Biol. Technol., 50 (2): 225-230.

Ekren, S.; C. Sonmez; E.Ozcakal; Y.Kurttas; E.Bayram and H.Gurgulu (2012). The effect of different irrigation water levels on yield and quality characteristics of purple basil (Ocimum basilicum L.). Agric. Water Manag., 109: 155161.

Epstein, E. and J.A. Bloom (2005).Mineral Nutrition of Plants: Principles and Perspective.Sinauer Associates, Inc. Sunderland, Massachusetts.

Gao, P. (2015). Agronomic and physiological impacts of irrigation frequency on green basil (Ocimum basilicum L .). M.Sc. Thesis, Fac. Sci.\& Tech. Lancaster Univ., UK.

Gao, X.; C. Zou; L. Wang and F. Zhang (2006). Silicon decreases transpiration rate and conductance from stomata of maize plants. J. Plant Nutr., 29(9):1637-1647.

Ghane, E.; M. Feizi; B.M. Farid and E. Landi (2010). Water productivity of winter wheat in different irrigation planting methods using saline irrigation water, Int. J. Agric. Bid., 11: 131-137. 
Gong, H.; K. Chen; G. Chen; S. Wang and C. Zhang (2003). Effects of silicon on growth of wheat under drought. J. Plant Nutr., 26 (5):1055-1063.

Hassan F.A.S. and E.F. Ali (2014). Impact of different water regimes based on class-A pan on growth, yield and oil content of Coriandrum sativum L. plant. J. Saudi Soci. Agric. Sci., 13: 155-161.

Hiltunen, R.; and Y. Holm (2003).Basil: the Genus Ocimum.CRC Press.

Hodson, M.J.; P.J.White; A. Mead and M.R. Broadley (2005). Phylogenetic variation in the silicon composition of plants. Ann. Bot., 96:1027-1046.

Hoel B.O. and K.A.Solhaug (1998). Effect of irradiance on chlorophyll estimation with the Minolta SPAD-502 leaf chlorophyll meter. Ann. Bot. - London 82: 389-392

Israelsen, O.W. and V.E. Hansen (1962). Irrigation Principles and Practices $3^{\text {rd }}$ Edit. John Willey and Sons. Inc., New York.

James, L.G. (1988). Principles of Farm Irrigation System Design. John Wil-ley\&Sons (ed.), New Yourk, 543 pp.

Kalteh, M.; Z.T. Alipour; F. S. AShra; M.M.Aliabadi and A.F. Sratabadi (2014). Effect of silica nanoparticles on basil (Ocimum basilicum) under salinity stress. J.Chem. Heal. Ris., 4(3): 49-55.

Kamkar, B.; A.R. Daneshmandb; F. Ghooshchic; A.H. Shiraniradd and A.R. Safahani (2011). The effects of irrigation regimes and nitrogen rates on some agronomic traits of canola under a semiarid environment. Agric. Water Manage., 98:10051012.

Karim., M.; R.M. Hime; J. Ferdush and M. Zakaria (2017). Effect of irrigation levels on yield performance of black cumin. Inter. J. Environ, Agric.\& Biotech., 2 (2):960-966.

Karmollachaab, A.; M.H. Gharineg; M. Bakhshandeh; M. Moradi, and G. Fathi (2014). Effect of silicon application on physiological characteristics and growth of wheat (Triticum aestivum L.) under drought stress conditions. Agroecology, 5(4): 430-442.

Keller, C.; M. Rizwan; J.-C. Davidian; O.S. Pokrovsky; N. Bovet; P. Chaurand; and J.-D. Meunier (2015).Effect of silicon on wheat seedlings (Triticum turgidum L.) grown in hydroponics and exposed to 0 to $30 \mu \mathrm{M} \quad \mathrm{Cu}$. Planta.,241(4):847-860.

Klute, A. (1986). Methods of Soil Analysis, part 1: Physical and Miner-alogical Methods $\left(2^{\text {nd }}\right)$ Ed. American Soci. of Agronomy, Madison, Wisconsin, USA.

Lakpale, R.; G. K. Shrivastava and R. S. Tripathi, (2007). Effect of irrigation schedule on growth,yield and economics of spice crops" Indian J. Agric. Sci., 77(3): 410-415.

Laware, S.L. and S. Raskar (2014) Effect of titanium dioxide nanoparticles on hydrolytic and antioxidant enzymes during seed germination in onion. Int. J. Curr. Microbiol. App. Sci., 3 (7):749-760.
Le,V.N ; Y.Rui ; X.Gui ; X. Li; S. Liu, and Y.Han, (2014):Uptake, transport, distribution and bioeffects of $\mathrm{SiO}_{2}$ nanoparticles in Bt-transgenic cotton. J. Nanobiotec., 12, 50.

Lee, S.-J.; K. Umano; T. Shibamoto; and K.-G. Lee (2005). Identification of volatile components in basil (Ocimum basilicum L.) and thyme leaves (Thymus vulgaris L.) and their antioxidant properties. Food Chem.,91(1).:131-137.

Letchamo, W.; H.L. Xu, and A. Gosselin (1999). Photosynthetic potential of Thymus vulgaris selections under two light regimes and three soil water levels. Sci. Hor., 62:89-101.

Ma, J.F.; Y.Miyake and E.Takahashi (2001): Silicon as a beneficial element for crop plants. Studies in Plant Sci., 8: 17-39.

Majumdar, D.K. (2002). Irrigation Water Management: Principles and Practice. $2^{\text {nd }}$ ed. Prentice Hall of India, New Delhi 110001, 487p.

Monica, R.C. and R. Cremonini (2009).Nanoparticles and higher plants. Caryologia.,62(2).:161-165.

Munns, R. and M. Tester (2008). Mechanism of salinity tolerance. Ann. Rev. Plant Phys., 59:651-681.

Moosavi, S.M.; S.G. Moosavi, and M.J. Seghatoleslami (2014). Effect of drought stress and nitrogen levels on growth, fruit and essential oil yield of fennel (Foenicolum vulgare Mill.). Iranian J. Med. Aroma. Plants, 30(3):453-462.

Page, A.L.; R.H. Miller and D.R. Keeney (1982). Methods of Soil Analysis -Chemical and Microbiological Properties. Madison, Wisconsin.

Pereira, M.R.R.; A.E.Klar; M.R.Silva; R.A.Souza and N.R. Fonseca (2006). Morphological and physiological behavior of clones from Eucalyptus urograndis submitted to different soil water levels. Irriga, 11: 518-531.

Rai, R. K. (2017) Planning and Evaluation of Irrigation Projects chapter 12 -Irrigation Scheduling. Academic Press.385-412.

Ram, D. ; M. Ram and R. Singh (2006). Optimization of water and nitrogen application to menthol mint (Mentha arvensis L.) through sugarcane trash mulch in a sandy loam soil of semi-arid subtropical climate. Bioresource Tec., 97:886893

Ram, M; D. Ram and S. Singh (1994). Irrigation and nitrogen requirements of bergamot mint on a sandy loam soil under sub-tropical conditions. Agric. Water Manag., 27 :45-54.

Robert, A. (1995). Identification of Essential Oils by Gas Chromatography- Mass Spectrometry. Allurd Pub., U.S.A.

Sajjadi, S.E. (2006). Analysis of the essential oils of two cultivated basil (Ocimum basilicum L.) from Iran. DARU J. Pharm. Sci.,14 (3).:128-130.

Shao, H. B.; L. Y.Chu; C. A.Jaleel and C. X. Zhao (2008). Water-deficit stress-induced anatomical changes in higher plants. C. R. Biol., 331: 21525 . 
Siddiqui, M.H and M.H. Al-Whaibi (2014) Role of nanoSiO2 in germination of tomato (Lycopersicum esculentum Mill.) seeds. Saudi. J .Biol. Sci., Jan.21:13-17.

Silva, O.N.; A.K. Lobato; F.W. Avila; L. Costa; F. Oliveira; B.G. Santos; A.P. Martins; R. Lemos; J. Pinho; M.B. Medeiros; M. Cardoso and I.P. Andrade (2012). Silicon-induced increase in chlorophyll is modulated by the leaf water potential in two water deficient tomato cultivars. Plant Soil Environ., 58:481-486.

Simon, J.E.; J. Quinn and R.G. Murray (1990). Basil: a source of essential oils, in: J. Janick and J.E. Simon (Eds.), Advances in new crops. Timber Press, Portland, OR. pp. 484-489.

Singh, M (2002). Effect of nitrogen and irrigation regimes on the yield and quality of sweet basil (Ocimum basilicum L.). J. Spices \& Arom. Crops, 11 (2): 151-154

Singh, M.; S. Sharma and S. Ramesh (2002). Herbage, oil yield and oil quality of patchouli [Pogostemon cablin (Blanco) Benth.] influenced by irrigation, organic mulch and nitrogen application in semi-arid tropical climate. Ind. Crops Prod.,16(2):101-107.

Snedecor, G. W. and W .G. Cochran.(1980). Statistical Methods, Seventh Edition (Ames, IA: The Iowa State University Press), Seventh Ed. Iowa, USA.
Sodaeizadeh, H. and F. Mansouri (2014). Effects of drought stress on dry matter accumulation, nutrient concentration and soluble carbohydrates of Salvia macrosiphon as a medicinal plant. Arid Biom.Scientific Res., 4(1):1-9.

Sommer, M.; D. Kaczorek; Y. Kuzyakov and J. Breuer (2006).Silicon pools and fluxes in soils and landscapes a review. J. Plant Nutr. Soil Sci.,169 (3).:310-329.

Vomocil, J.A. (1957). Measurement of soil bulk density and penetrability: A review of methods. Adv. Agron., 9: 159-175.

Wang, J. and N. Naser (1994). Improved performance of carbon paste amperometric biosensors through the incorporation of fumed silica. Electroanalysis., 6(7):571-575.

Zehtab-Salmasi, S.; A. Javanshir; R. Omidbaigi; H. Alyari and K. Ghassemi-Golezani (2001).Effects of water supply and sowing date on performance and essential oil production of anise (Pimpinella anisum L.). Acta Agron. Hungarica.,49 (1):7581.

Zhu, Y.; and H. Gong (2014).Beneficial effects of silicon on salt and drought tolerance in plants. Agron. Sustain. Dev.,34 (2):455-472.

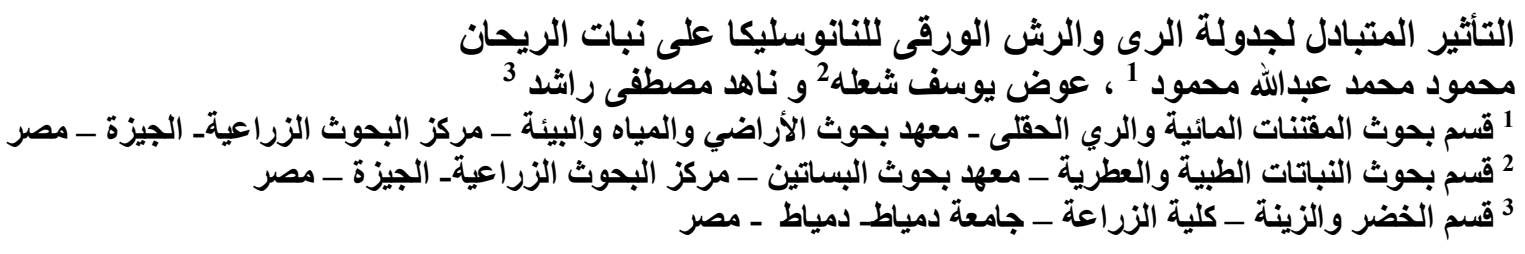

أجريت هذه الدر اسة بمحطة البحوث الزر اعية بسخا ـ بمحافظة كفر الثيخ عامى 2016 , 2017 بهدف دراسة التاثير المنبادل

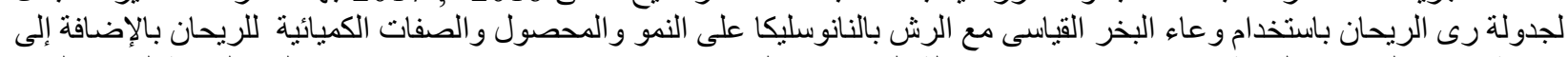

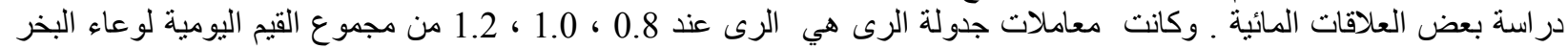

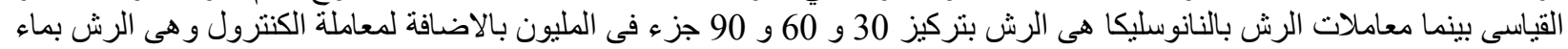

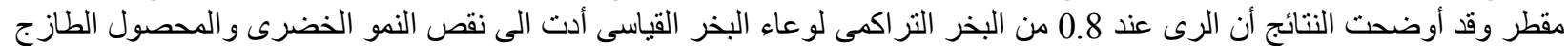

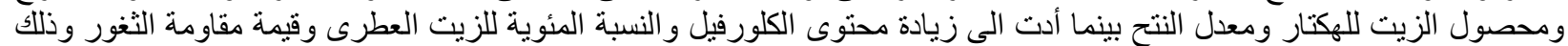

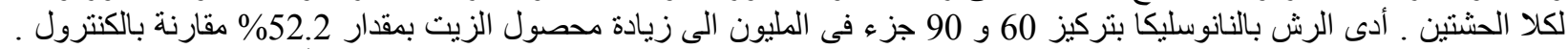

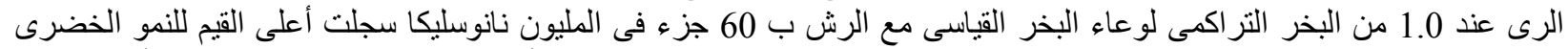

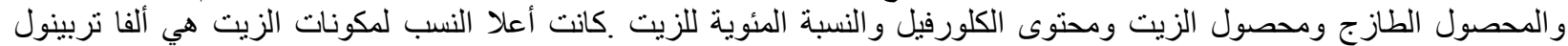

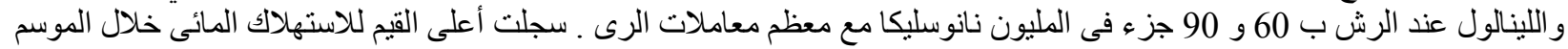

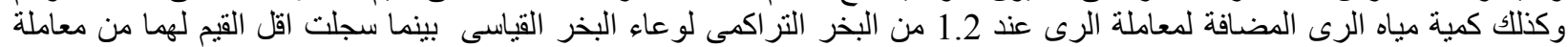

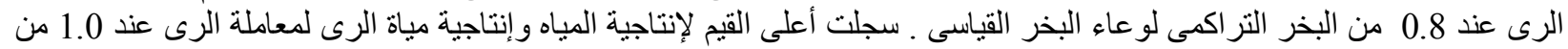

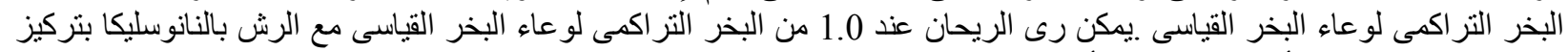

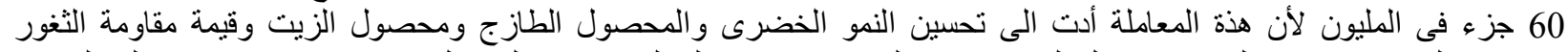

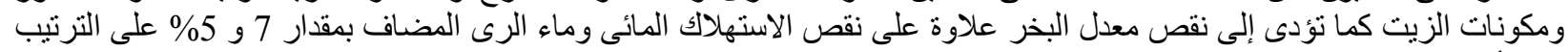

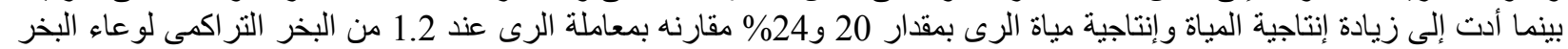

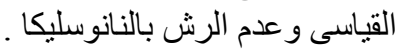

